\title{
Analysis of Performance Measurement Using The Balanced Scorecard Method (BSC): Case Study of PT. Perusahaan Listrik Negara (PERSERO) Distribusi Jawa Timur Area Pelayanan dan Jaringan Surabaya Selatan)
}

\author{
Oryza Tannar and Riza ${ }^{1}$, Rida Perwita Sari and Rida ${ }^{2}$, Endah Susilowati and Endah ${ }^{3}$, Sari \\ Andayani and Sari ${ }^{4}$, Anik Yuliati and $\mathrm{Anik}^{5}$ \\ \{oryza.tannar.ak@upnjatim.ac.id ${ }^{1}$, rida.ps.ak@upnjatim.ac.id ${ }^{2}$, endahs.ak@upnjatim.ac.id, \\ sariandayani.ak@upnjatim.ac.id, anik.yuliati.ak@upnjatim.ac.id \\ 1,2,3,4,5 Universitas Pembangunan Nasional "Veteran“ Jawa Timur, Jalan Raya Rungkut Madya Gunung \\ Anyar, Indonesia
}

\begin{abstract}
Procurement is expected to be carried out effectively and efficiently with the principles of fair competition, transparent ,opened and fair treatment for all parties, in accordance with Peraturan Presiden Nomor 54 Tahun 2010 on Government Procurement is an activity to obtain goods and services by the Ministry / Institutions / Regional Working Units / other Institutions starting from the planning process needs to be disclosed all activities to obtain goods and services. As the development of an increasingly modern era, the government infrastructure was varied to keep track of and adapted to the needs of the government. The procurement of goods and services financed by the budget of revenues and expenditures country / region. This study focuses on government procurement of goods and services made in the area of PT. PLN Disjatim by using the historical approach, sociological approach, institutional approaches, legal and political approach to development based on risk management. The data in this study were obtained by physical or direct data approach with several parties and employees concerned with the procurement of goods and services within the state electricity distribution company of the Eastern Java.The results of this study include the procurement of goods and services in the state electricity company disjatim generally been in accordance with the systems and mechanisms that have been defined in the Peraturan Presiden 54 Tahun 2010 on Government Procurement. However, once studied and reviewed more deeply there are some constraints and the presence of fraudulent behavior committed by the procurement committee and procurement participants and parties involved in the procurement of goods and services.
\end{abstract}

Keywords: procurement of goods and services, the company states, risk management 


\section{Introduction}

This Word document can be used as a template for journal. This Word document can be used as a template for journal. This Word document can be used as a template for journal. This Word document can be used as a template for journal. This Word document can be used as a template for journal In the present is with the rapid development of business in the domestic and overseas businesses resulted in increased competition both from domestic and abroad. Therefore, many managers in various industries thinking of better ways of measuring business performance is in progress, these measurements can be used to assess the success of the company. Measurement model of the old (traditional), the measurement by seeing at the work of an organization described in the financial statements are perceived not to be used because it is not in accordance with the progress and sophistication of current technological developments that require the ability to comprehensively improve their performance. More over by the move toward the era of free global market that demands for each company to execute its strategy in the face of competition and use its resources more effectively and efficiently, which ultimately the company's vision can be achieved. In order to survive and compete, the main factors that must be owned companies is their ability in following the developments there, both external and internal as well as managing proportionately.

PT. PLN (Persero) is a service company providing electricity service. PLN electricity generating, transmitting and distributing to its customers. Production of electricity in the form of electrical energy, and then utilized by customers for various purposes of life, including as a source of light energy, mechanical energy source, and so forth. Because of the importance of such power in people's lives depend, and the binding by electricity, the energy needs of the present moment has become the main (primary) for the community. Would be inconceivable if the distribution of electric power must be disconnected in a city one day, various activities of life will be disrupted even be halted altogether. Can be seen in everyday life, necessary lighting, electric water pump, fan, air conditioning, traffic lights and much more. PLN provides electricity supply services, customers satisfy these services, then by PLN customers bear the costs for services rendered.

To measure how much money to be paid by a customer to PLN, the unit of energy measurement that is used or kilo watt hour. The unit is measured by a gauge mounted kWh meters consumer site. Thus, that PLN obtain its revenues from $\mathrm{kWh}$ sales to consumers. The greater consumption of energy consumed by customers the greater electricity bills to customers, and the greater cumulative $\mathrm{kWh}$ of electricity sold to all customers of PLN, the PLN's revenues as a whole will also rise.

In this company there is still a performance measurement system that is comprehensive or exhaustive, for this size of company performance more focused only on the side just financial Therefore the use of Balanced Scorecard design are needed and expected to eliminate the weaknesses of performance measurement to the Analysis of Financial Report (financially) by adding the measures of success of non-financial perspective, among others: customer, internal business processes and learning and growth.

Balanced Scorecard is a method of performance measurement techniques that not only uses the measurement of financial constraints in assessing the performance of a company, here are three non-financial perspective which is also used within the limits of performance measurement from the perspective of corporate customers, internal business process perspective and learning and growth perspective. The method of Balanced Scorecard is a business evaluation techniques and firm performance in a comprehensive, coherent, measurable and modern. Because the extent of implementation of the Balanced Scorecard in the business concept, then a narrow definitions sometimes feels compared with the balanced scorecard function actually accomplishes. Meanwhile, to agree on a definition that can handle a region where the Balanced Scorecard to 
work is not easy. Therefore, any approach in order to socialize the Balanced Scorecard should be seen as an attempt to describe the concept of Balanced Scorecard in each part (Yuwono, et al., 2006:6)

According to Kaplan and Narton (1996), The Balanced Scorecard is:

".... A set of measures That gives top managers a fast but comprehensive view of businees ... includes financial and Measures tha tell the result of actions already taken ... complements the financial measures on custemer satisfaction, internal process, and the organizatiaon's innovation and improvement activities operatioanal That maesures are the drivers of financial performance "

From the above definition can be concluded that the measurement of performance measurement is an act committed against a variety of activities in value chains that exist in the company. The measurement results are then used as feedback that will provide information about the achievements of the implementation of a plan and the point where companies require adjustments for activity planning and control. (Mulyadi, 2001:44-45).

\section{Through the Balanced Scorecard Performance Measurement}

Balanced Scorecard is appropriate degan types of operations lately coveted by many companies, where the focus of attention is placed on the company's vision and corporate strategy.

Balanced Scorecard also serves as a means of communication strategy that includes a message to all employees about the importance of pursuing a balanced view and to the purpose (objectives) of each perspective. This concept also can provide a comprehensive framework for executives to translate company vision into strategic objectives at the Operational level in several sets of performance appraisal are assembled logically to one another.

Through the Balanced Scorecard to highlight the performance of the management company of the four different perspectives, with authorized capital questions as below :

- $\quad$ To succeed financially, how should the company be viewed by shareholders.

- To achieve the company vision, how the consumer views on the company.

- To satisfy customers and shareholders, business processes, such as what was seeded.

- To achieve the vision of the company, whether the company can make improvements and create added value on an ongoing basis.

\section{Analytical Hierarchy Process (AHP)}

\section{The Procedure of Analytical Hierarchy Process}

In general, the steps that must be done in using AHP is as follows (Suryadi and Ramdhani, 1998) :

1. Defining the problem and determine the specific objectives and the desired solution. If used to select alternatives or to prioritize alternatives, at this stage is to develop an alternative.

2. Formulate the problem into a hierarchical structure so that complex problems can be seen from the detail and measurable. The preparation of the hierarchy that meets the needs should involve experts in the field of decision-making.

3. Constructing pairwise comparison matrices for each level below it, a matrix for each element right at the level above it. The elements at lower levels compared to each other based on the impact on the right elements at the level above it. The result is a square matrix of judgments.

4. Completion of pairwise comparison matrix by decision makers. It takes as many as n ( $\mathrm{n}$ 1) / 2 judgment for each matrix in Step 3 above. 
5. Consistency test by using the eigen value of pairwise comparison among the elements obtained at each level of hierarchy. First, test the consistency index value, calculate the ratio of consistency index values and index randoms.

6. 3,4 and 5 repeated every level of the cluster and hierarchy.

7. Perform synthesis to construct the weight vector of each element eigenvalue problems at each level of hierarchy. This process will result in achieving weight elements, so that the element with the highest weight has priority handling. Priority is produced from a matrix of pairwise comparison between all the elements at the same level.

8. Evaluating the consistency of the hierarchy, if its value is greater then 0.1 occurred inconsistencies, data quality must be improved.

Priority Arrangement

The first step in setting priorities for the elements is to make paired comparisons, ie comparing pairs in the form of all elements for each subsystem hierarchy. Comparisons are then transformed into matrix form for the purpose of numerical analysis.

Suppose there is a hierarchy of subsystems with a single criterion $C$ and the number of $n$ elements underneath. $A_{1}$ until $A_{n}$ as shown in Figure 2.3. Comparison nxn matrix called the matrix $A$ as shown in table 2.1. The matrix is called the matrix of pairwise comparison.

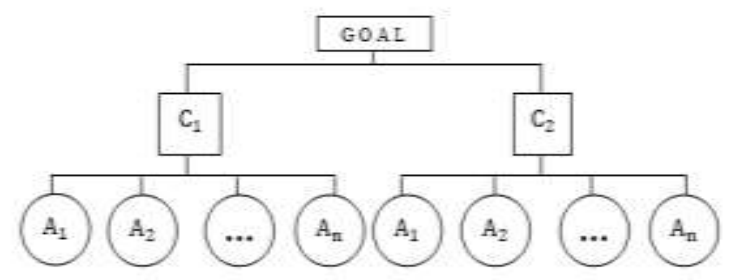

Figure 2.8 'Subsystem Hierarchy'

Source: Thomas L. Saaty: "Decision Making for Leaders' 1993

Table 2.1: Example of Pairwise Comparison Matrix

\begin{tabular}{c|ccccc}
$\mathrm{C}$ & $\mathrm{A}_{1}$ & $\mathrm{~A}_{2}$ & $\mathrm{~A}_{3}$ & $\ldots$ & $\mathrm{A}_{\mathrm{n}}$ \\
\hline $\mathrm{A}_{1}$ & $a_{11}$ & $a_{12}$ & $a_{13}$ & $\ldots$ & $a_{1 n}$ \\
$\mathrm{~A}_{2}$ & $a_{21}$ & $a_{22}$ & $a_{23}$ & $\ldots$ & $a_{2 n}$ \\
$\mathrm{~A}_{3}$ & $a_{31}$ & $a_{32}$ & $a_{33}$ & $\ldots$ & $a_{3 n}$ \\
$\ldots$ & $\ldots$ & $\ldots$ & $\ldots$ & $\ldots$ & $\ldots$ \\
$\mathrm{A}_{\mathrm{n}}$ & $a_{n 1}$ & $a_{n 2}$ & $a_{n 3}$ & $\ldots$ & $a_{n n}$
\end{tabular}

Source: Thomas L. Saaty 'Decision Making for Leaders' .1993

Value of $a_{i j}$ is the value of $a_{i}$ the element to $a_{j}$ the elements which states the relationship: - What is the level of interest $a_{i}$ when compared $a_{j}$, or

d How much contribution $a_{i}$ when compared with the $a_{j}$, or 
- How far domination $\mathrm{a}_{\mathrm{i}}$ when compared with $\mathrm{a}_{\mathrm{j}}$, or

- How many properties as $\mathrm{a}_{\mathrm{i}}$ compared to the criteria of $\mathrm{a}_{\mathrm{j}}$.

If known $a_{i j}$ value, then the theoretical value of $a_{i j}=1 / a_{i j}$, whereas the numeric value imposed for the above comparison is obtained from the scale of comparison made by Thomas $\mathrm{L}$. Saaty in Table 2.2.

Table 2.2 Assessment Scale AHP Pairwise Comparison

\begin{tabular}{|c|l|}
\hline Numeric Value & \multicolumn{1}{|c|}{ Qualitative Scale and Definitions } \\
\hline $\mathbf{1}$ & $\begin{array}{l}\text { Importance weight of decision elements which one is considered 'equal } \\
\text { importance'. }\end{array}$ \\
\hline $\mathbf{3}$ & $\begin{array}{l}\text { Importance weight of decision elements which one is considered 'less } \\
\text { important' than the other decision elements. }\end{array}$ \\
\hline $\mathbf{5}$ & $\begin{array}{l}\text { Importance weight of decision elements which one is considered 'quite } \\
\text { important' than the other decision elements. }\end{array}$ \\
\hline $\mathbf{7}$ & $\begin{array}{l}\text { Importance weight of decision elements which one is considered 'very } \\
\text { important' compared to the other decision elements. }\end{array}$ \\
\hline $\mathbf{9}$ & $\begin{array}{l}\text { Importance weight of decision element is graded 'absolute (very important)' } \\
\text { than the other decision elements. }\end{array}$ \\
\hline $\mathbf{2 , 4 , 6 , 8}$ & $\begin{array}{l}\text { 'Median Values' Given a valuation if there is any doubt between 2 (two) } \\
\text { adjacent assessments. }\end{array}$ \\
\hline
\end{tabular}

Source : Multi Criteria Decision Making: The Analytic Hierarchy Process, Thomas L. Saaty, 1998.

\section{Measurement of Consistency Every Matrix Comparison}

Consistency is the type of measurement can not just happen or have certain conditions. A matrix, for example there are 3 elements (i, j, k) and each comparison expressed by a. Consistency $100 \%$ if it meets the following requirements.

$$
a_{i j} \cdot a_{j k}=a_{i k}
$$

with these requirements then the following matrix A can be expressed consistency because:

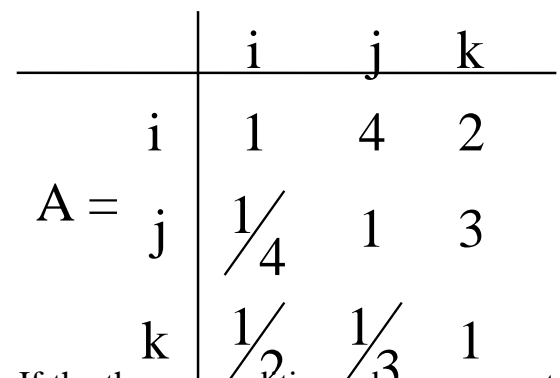

If the thrqee condtions above are met then the matrix A can be said that the consistency of $100 \%$ or it can also be said inkonsistensinya $0 \%$ level. When appears the number or scale of 5 in a matrix of comparison then it's none other than the $5 / 1$. With that basis it was explained that: Therefore,

$$
\mathrm{a}_{\mathrm{ij}}=\mathrm{w}_{\mathrm{i}} / \mathrm{w}_{\mathrm{j}} \text {, where } \mathrm{i}, \mathrm{j}=\text { natural numbers }
$$

$$
a_{i j} \cdot a_{j k}=\left(w_{i} / w_{j}\right) \cdot\left(w_{j} / w_{k}\right)=w_{i} / w_{k}=a_{i k}
$$

and also can be proved that:

$$
\mathrm{a}_{\mathrm{ji}}=\mathrm{w}_{\mathrm{j}} / \mathrm{w}_{\mathrm{i}}=1 /\left(\mathrm{w}_{\mathrm{i}} / \mathrm{w}_{\mathrm{j}}\right)=1 / \mathrm{a}_{\mathrm{ij}}
$$


If the number of $\mathrm{n}$ equations with $\mathrm{n}$ unknown variables solved by matrix then form the matrix equation becomes:

A . $\mathrm{x}=\mathrm{Y}$

Where $\mathrm{A}$ is the matrix containing the coefficient - the coefficient of all equations. $\mathrm{x}$ is a variable that would look great and $\mathrm{Y}$ is a constant on the right side of each equation. The formula (1) can also be expressed as:

$\sum_{j=1}^{n} a_{i j} \cdot x_{i}=y_{i}$, where $\mathrm{i}=$ natural number

Because,

$a_{i j} \cdot\left(w_{j} / w_{i}\right)=1$, where $\mathrm{i}, \mathrm{j}=$ natural number

or

$\sum_{j=1}^{n} a_{i j} \cdot w_{j} \cdot\left(1 / w_{i}\right)$, where $\mathrm{a}, \mathrm{i}=$ natural number

Then

$\sum_{j=1}^{n} a_{i j} \cdot w_{j}=n \cdot w_{i}$, where $\mathrm{i}=$ natural number

Which is equal to

A . $\mathrm{w}=\mathrm{n} . \mathrm{w}$

In matrix theory, the formula (2) shows that $\mathrm{w}$ is the eigen investors from matrix $\mathrm{A}$, while $n$ indicates eigen its value.

Measurement of the consistency of a matrix itself is based on a maximum eigen value. With the maximum eigen value, the usual inconsistencies resulting comparison matrix can be minimized.

The formula of consistency index $(\mathrm{CI})$ is

$$
C I=\frac{\left(\lambda_{\text {maks }}-n\right)}{(n-1)}
$$

The following random index for the matrix size is 3 to 10 (matrks size 1 and 2 have inconsistencies 0 ).

Table 2.3 Value of the Random Index (RI)

\begin{tabular}{|c|c|c|c|c|c|c|c|c|}
\hline 1,2 & 3 & 4 & 5 & 6 & 7 & 8 & 9 & 10 \\
\hline 0,00 & 0,58 & 0,90 & 1,12 & 1,24 & 1,32 & 1,41 & 1,45 & 1,49 \\
\hline
\end{tabular}

Source : Analitical Hierarchy Process, Bambang Brodjonegoro, 1991

The formula of consistency / inconsistency (CR) itself can be written as follows:

$\mathrm{CR}=\mathrm{CI} / \mathrm{RI}$

where : $\mathrm{CR}=$ Consistency Ratio

$$
\begin{aligned}
& \mathrm{CI}=\text { Consistency Index } \\
& \mathrm{RI}=\text { Random Index }
\end{aligned}
$$

Level of inconsistency that is still acceptable is the level of inconsistency bias of $10 \%$ down (Brodjonegoro, 1991: 15)

\section{Questionnaires}

\section{Definition of Questionnaires}

According to Safirin (2002: 65), a questionnaire is a means of communication between researchers by people who studied / respondent, a list of questions, which were distributed by the researchers weeks to be filled by the respondent.

Questionnaire distinguished (in practice anglosaxon) a written questionnaire and interview questionnaire used by researchers as a handle in an interview. 


\section{Preparation of Questionnaires}

Filling in questionnaires for filling the questionnaire does not take too long, then there are requirements that must be appropriate, which is

a. Using the discussion simple, easily understandable, everyday language that is used according to the respondents.

b. Using short sentences.

c. Not considering the respondents had specific knowledge or experience.

d. Protecting self-esteem respondents.

e. Avoiding ambiguous sentences.

f. Each question presents one mind.

g. Start with easy questions and draw up to a tough question.

h. Placing a personal question at the end of questionnaires.

\section{Research Method}

\section{Research Approach}

This research method is a research design that would logically explain the relationship between the formulation of a problem with the methods to be applied, so that the research method chosen should match the research question.

This study used a qualitative approach with qualitative descriptive methods. This approach is used because it fits the background of the problem, the formulation of the problem and research purposes. According to Bagdan and Taylor (Moleong, 2000:3) "A qualitative approach is defined as research procedures which produce descriptive data in the form of data written or verbal from the people and behaviors that can be observed. This approach is directed at the individual's background and in full ". Another definition is disclosed by Kirk and Miller (Moleong, 2000:3) "Qualitative research is a particular tradition in social science that is fundamentally dependent on the observations in humans in the region itself and relate to people in language and in its technical term".

According to Yin (2001:1), an approach that uses data in the form of sentences written or oral, behaviors, phenomena, events, events, knowledge or object of study. The research process provides the context of studies focusing on understanding, thought and perception researchers. Case study due to the appropriateness of the questions on the formulation of the problem in this study "How to evaluate the implementation of the Balanced Scorecard as a tool for measuring performance at PT. PLN (Persero)?" with the characteristics of the case study method, whereby:

1. The case study is an appropriate study to answer a problem formulation that uses a "how" or "why".

2. The study of human needs as a researcher and human being has no power over the phenomenon being studied.

3. Research carried out lies in the contemporary phenomenon (the present) within the context of real life.

According to Nazir (1998:63) descriptive method is a method in researching the status of groups of people, an object, a set of conditions, a system of thought or a class of events in the present. The purpose of descriptive research is to create a description, picture or painting in a systematic, factual, and actual on the facts, the properties and the relationship between the phenomena being investigated.

Data used in this study was obtained from PT. PLN (Persero) Distribusi Jawa Timur Area Pelayanan dan Jaringan Surabaya Selatan, located at Jalan Ngagel Timur No. 14-16 Surabaya 
60283, East Java Province. Time data collection, both primary data and secondary data starting from October 2010 until the necessary data if sufficient. Then, Data analysis technique is performed by using Expert Choice 11 edition software and the results are generalized based on the outcome and predetermined criteria.

Weighting of Four Balanced Scorecard Perspectives Reject Measure With Each Balanced Scorecard Perspective.

Weighting technique is used to determine the level of importance and role of the four perspectives and benchmarks of each perspective for improving corporate performance in the future is Analytical Hierarchy Process (AHP).

The order of completion of weighting by using the AHP method, is as follows:

1. Weighting the four perspectives of BSC with Pairwise Comparison Matrix.

Table 3.1 : Example of Pairwise Comparison Matrix Table 4 BSC

Perspective

\begin{tabular}{lcccc}
\multicolumn{1}{c|}{ Objectives } & Financial & Customer & $\begin{array}{c}\text { Internal } \\
\text { Business } \\
\text { Process }\end{array}$ & $\begin{array}{c}\text { Learning and } \\
\text { Growth Process }\end{array}$ \\
$\begin{array}{l}\text { Financial } \\
\text { Customer } \\
\text { Internal Business }\end{array}$ & 1 & 1 & 1 & \\
$\begin{array}{l}\text { Process } \\
\text { Learning and Growth } \\
\text { Process } \\
\text { Total }\end{array}$ & & & 1 \\
\end{tabular}

2. Preparation of Comparative Matrix Normalization Results

Table 3.2: Example of Matrix Comparison Table, 4 Normalized Results BSC Perspective

\begin{tabular}{|l|l|l|l} 
Objectives & Financial Customer & $\begin{array}{c}\text { Internal } \\
\text { Businesws } \\
\text { Process }\end{array}$ & $\begin{array}{c}\text { Learning } \\
\text { and Growth } \\
\text { Process }\end{array}$
\end{tabular} Amount Weight

Financial
Customer
Internal
Business
Process
Learning and
Growth
Process

Process

3. Consistency test. The way is as follows:
a. Priority : $\lambda_{\text {maks }}=\sum \frac{\left(\frac{Y}{X}\right)}{n}$
b. Consistency Index : $C I=\frac{\left(\lambda_{\text {maks }}-n\right)}{(n-1)}$ 
c. Consistency Ratio : $C R=\frac{C I}{R I}$, matrix is consisten, if $\mathrm{CR} \leq 0,1$

4. Furthermore, for each BSC perspective is weighted with the same steps as the steps above. Each Performance Measurement Balanced Scorecard Perspective

The next step is to measure company performance. Measurement starts with the assessment of the performance of each benchmark used in each perspective of BSC. Rating (score) the better performance, if the results achieved from a benchmark has a value close to the target company. Scores of the benchmarks will be multiplied between benchmark scores with weights which is the value of the benchmark's performance. The value of performance from a perspective derived from the sum of the value of performance benchmarks. An example table is as follows:

Table 3.3: Sample Table of Performance Measurement Perspective ' $X$ '

No Objectives Benchmarks Value Score Weight Amount

\section{Total}

\section{Overall Corporate Performance Measurement}

Company's overall performance value obtained by multiplying the value of the performance of each company's perspective of the Balanced Scorecard perspectives with the weight of the interests which have been determined. The higher number means the value obtained by the better performance of the company. By using the Sturges rule, criteria for assessment of the total results of the assessment taken by the score. The range between the largest score (value 3) and smallest (value 1) divided by the number of classes, in this case is 3 (good category, simply, bad) then increment its value obtained by 0.67 . Thus, the assessment criteria to measure overall company performance, as follows:

$1,00 \leq$ total measurement results $\leq 1,67$

$1,68 \leq$ total measurement results $\leq 2,35$

Less Comparity Performance

$2,36 \leq$ total measurement results $\leq 3,00$

Enough Comany Performance

Good Comp Performance

\begin{tabular}{l}
\multicolumn{1}{c}{ Perspective } \\
Financial \\
Customer \\
Internal Business Process \\
Learning and Growth \\
Process
\end{tabular}

Total

\section{Result and Discussion}

\section{Identification of Vision, Mission and Corporate Strategy}

PT. Perusahaan Listrik Negara (Persero) is a service company providing electricity service. PLN generate electricity, deliver and distribute to customers. The company is trying to develop a Strategic Business Unit (SBU), in order to maintain the company's overall survival. 
Vision and mission as a guideline for component companies to develop themselves and align corporate objectives that support achievement of the vision and mission.

Vision of PT. State Electricity Company is

\section{"Recognized in 2012 as a distribution unit with world class service and excellent customer} satisfaction and put cultural integrity."

Company's vision is a future desire that contain a lot of challenges and able to raise the motivation of all company personnel in achieving organizational goals of the company. At this time only in the domestic market only, ie in some areas of the city in East Java, is marketing the region will continue to be developed throughout the entire city of Indonesia.

The mission of this company are the things to be achieved by the company, while the mission of PT. State Electricity Company is

a. Transparent to service that provides customers with quick, accurate due diligence and integrity.

b. Running a business electricity and other related business fields oriented in customer satisfaction, member of the company and shareholders.

c. Making electricity as a medium to improve the quality of community life.

d. Oriented for repairmen service to improve customer satisfaction.

Owners of capital or the owner wants for the company will have good financial skills, because if not then the owner will certainly be felt loss of capital to invest its capital in the company. Customer is a company asset that must be maintained and enhanced, because the company forward pullback will depend on customer factors, and the customer factor that will affect the achievement of goals.

The company's strategy is the basis for partnering strategy, and internal consolidation in order to enhance enterprise competitiveness. The strategy of PT. Perusahaan Listrik Negara are:

1. Improving the ability of the company in sufficient own financial needs with increased returns obtained by a business entity for any investment.

2. Strengthen corporate image and expand business networks in market share.

3. Minimizing the level of customer complaints by providing the best service. The number of customer complaints / customer showed less satisfied customers for its services, provided by the company.

4. Increasing the productivity of labor in order to face intense competition.

5. Improving the competence or the quality of Human Resources (HR) through training to improve customer satisfaction and develop the skills of Human Resources (HR).

A good strategy to support the achievement of a vision but does not always guarantee the achievement of that vision, and therefore the achievement of the vision is not only determined by the existence of a good strategy but also the good and bad execution of strategy. Implementation of the strategy is considered good or bad it also depends on the ability and the involvement of all employees of the company.

\section{Relationship with Learning and Growth Process Problems}

Based on benchmarks Percentage Number of Employees Absent, Percentage of Employee Turn Over, Percentage Number of Employees follow Training (Employee Training), will cause companies to increase organizational productivity. This is in accordance with the principles of efficiency and effectiveness that it was related to the Learning and Growth perspective.

When all four benchmarks are established to meet the target, it will be an increase in corporate earnings, which means the company's profitability will increase as well.

\section{Data Collection} follows:

The data used to measure performance using the Balanced Scorecard method, are as 


\section{Financial Perspective}

In the financial perspective, the data used in the calculation of ROI, ROE, AM, and SG, derived from the balance of 2008 and 2009, and reports of losses / gains in 2008 and 2009 (contained in the appendix 1).

Table 4.1 Summary of Secondary Data Financial Perspective

\begin{tabular}{|c|c|c|}
\hline Data & $\mathbf{2 0 0 8}$ & $\mathbf{2 0 0 9}$ \\
Description & & \\
\hline Total Sales & 2.079 .311 .684$. & 2.183 .952 .85 \\
& 310 & 5.607 \\
\hline Net Income & $(389.401 .881$. & $(318.464 .70$ \\
After Tax & $112)$ & $6.910)$ \\
\hline Total Assets & 411.595 .075 .1 & 422.659 .504$. \\
& 31 & 799 \\
\hline Total Equities & $(389.401 .881$. & $(318.464 .70$ \\
& $112)$ & $6.910)$ \\
\hline
\end{tabular}

Source: Internal Data Company

In 2008 total sales reached Rp.2.079.311.684.310, - while in 2009 an increase of up to Rp. 2,183,952,855,607, -. On the net profit after tax increased from Rp. (389 401881 112), - to Rp. (318,464,706,910), -. The total assets in 2008 reached Rp.411.595.075.131, - which was increased by Rp.422.659.504.799 , -. While the amount of capital to Rp. (389 401881 112), - in 2008 and in 2009 amounted to Rp. (318,464,706,910), -.

\section{Customer Perspective}

In the perspective of the customer data required are:

Table 4.2 Summary of Secondary Data Customer Perspective

Number of Service Complaints

\begin{tabular}{|c|c|c|}
\hline $\begin{array}{c}\text { Number of Customer } \\
\text { Complaints Service }\end{array}$ & $\mathbf{2 0 0 8}$ & $\mathbf{2 0 0 9}$ \\
\hline Others & 15 & 6 \\
\hline Voltage Quality & 3 & 1 \\
\hline Disorders Service & 4 & 0 \\
\hline Meter Readings & 8 & 8 \\
\hline Customer Service & 23 & 13 \\
\hline Total & 53 & 28 \\
\hline
\end{tabular}

Source: Internal Data Company

In 2008 the number of complaints by customers due to late and not in accordance with the criteria, the other factor reaches 15 , the quality of the voltage reaches 3 , the service disruption to 4 , and the meter reading reaches 8 while in the customer service reached 23 while in 2009 decreased at other factors to 6 , the quality of the voltage has decreased to 1 , the service disruption to 0 , while the meter reading remains at 8 , and on customer service has decreased to 13 .

Table 4.3 Summary of Secondary Data Customer Perspective

Number of Transactions

\begin{tabular}{|c|c|c|}
\hline Total Transaction & $\mathbf{2 0 0 8}$ & $\mathbf{2 0 0 9}$ \\
\hline Kwh Purchases & 3099 & 3238 \\
\hline Kwh Sales & 2862 & 3012 \\
\hline Distribution Losses & 237 & 226 \\
\hline Total & 6199 & 6477 \\
\hline
\end{tabular}




\section{Source: Internal Data Company}

In 2008 the number of transactions on purchase kwh reached 3099 and in 2862, while sales reached on distribution losses reached 237, while in 2009 an increase in kwh purchases until 3238, in kwh sales reached 3012, and the shrinkage of distribution has decreased to 226.

Table 4.4 Summary of Secondary Data Customer Perspective

\begin{tabular}{|c|c|c|}
\hline \multicolumn{3}{|c|}{ Number of New Customers } \\
\hline $\begin{array}{c}\text { Total of New } \\
\text { Customer }\end{array}$ & $\mathbf{2 0 0 8}$ & $\mathbf{2 0 0 9}$ \\
\hline New Customer & 9404 & 8316 \\
\hline
\end{tabular}

Source: Internal Data Company

In 2008 the number of new subscribers reached 9404, whereas in the year 2009 decreased until 8316.

Table 4.5 Summary of Secondary Data Customer Perspective Total Customers

\begin{tabular}{|c|c|c|}
\hline Total Customers & $\mathbf{2 0 0 8}$ & $\mathbf{2 0 0 9}$ \\
\hline Customers & 385376 & 393692 \\
\hline
\end{tabular}

Source: Internal Data Company

In 2008 the number of subscribers reached 385,376, whereas in the year 2009 reached 393,692 .

\section{Internal Business Process Perspective}

On the internal business process perspective the data required are:

Table 4.6 Summary of Secondary Data Internal Business Process Perspective

Number of Transactions

\begin{tabular}{|c|c|c|}
\hline Total Transaction & $\mathbf{2 0 0 8}$ & $\mathbf{2 0 0 9}$ \\
\hline Kwh Purchases & 3099 & 3238 \\
\hline Kwh Sales & 2862 & 3012 \\
\hline Distribution Losses & 237 & 226 \\
\hline Total & 6199 & 6477 \\
\hline
\end{tabular}

Source: Internal Data Company

In 2008 the number of transactions on purchase kwh reached 3099 and in 2862, while sales reached on distribution losses reached 237, while in 2009 an increase in kwh purchases until 3238 , in kwh sales reached 3012, and the shrinkage of distribution has decreased to 226.

Table 4.7 Summary of Secondary Data Internal Business Process Perspective Number of Working Hours

\begin{tabular}{|c|c|c|}
\hline $\begin{array}{c}\text { Number of } \\
\text { Working } \\
\text { Hours } \\
\text { Effective }\end{array}$ & $\mathbf{2 0 0 8}$ & $\mathbf{2 0 0 9}$ \\
\hline $\begin{array}{c}\text { Effective } \\
\text { Number of } \\
\text { Working Hours }\end{array}$ & 2128 & 2144 \\
\hline
\end{tabular}

In 2008 the number of effective working hours of 2128 and in 2009 reached 21443. 
Learning and Growth Perspective

In the process of learning and growth perspective is needed is

Table 4.8 Summary of Secondary Data Perspective

Learning and Growth

\begin{tabular}{|c|c|c|}
\hline Data Description & $\mathbf{2 0 0 8}$ & $\mathbf{2 0 0 9}$ \\
\hline $\begin{array}{c}\text { Total Average Days } \\
\text { of Employee Absent }\end{array}$ & 2 & 3 \\
\hline $\begin{array}{c}\text { Effective Number of } \\
\text { Working Hours }\end{array}$ & $\begin{array}{c}8 \text { hours } \\
\text { of } \\
\text { effective } \\
\text { work }\end{array}$ & $\begin{array}{c}8 \text { hours } \\
\text { of } \\
\text { effective } \\
\text { work }\end{array}$ \\
\hline $\begin{array}{c}\text { Number of } \\
\text { Employees Training }\end{array}$ & 134 & 109 \\
\hline $\begin{array}{c}\text { Average Number of } \\
\text { Employees Who } \\
\text { Worked }\end{array}$ & 266 & 268 \\
\hline Total Working Days & 246 & 250 \\
\hline $\begin{array}{c}\text { Total Employees } \\
\text { Out }\end{array}$ & 19 & 20 \\
\hline
\end{tabular}

Source: Internal Data Company

Total days on average employees who do not come to work (absent) in 2008 reached 2 days / year and in 2009 reached 3 days / year. Most of those experiencing problems related illness, and family affairs (relatives who died, the child is sick and should be treated in hospital, etc.). The number of effective working hours in 2008 and 2009 is 8 hours of effective work. The number of employees training in 2008 reached 134 and in 2009 reached 109. The average number of employees who work from year to year has increased, most of them resigned and the evaluation process konduite work or on the contrary, in 2008 employees are working to reach 266 employees, the year 2009 reached 268 employees, in 2008 as many as 246 days, and in 2009 of 250 days. The number of employees who came out in 2008 reached 19 people, in the year 2009 reached 20 people, with reason to resign and work konduite evaluation process.

Results from the calculation of factors of success in each perspective of Balanced Scorecard can be seen in Table 4:18, the following:

Table 4.14 Summary of Measurement of Critical Success Factors Each Balanced Scorecard Perspective

\begin{tabular}{|c|c|c|c|}
\hline \multirow{2}{*}{ Perspective } & $\begin{array}{c}\text { Standard } \\
\text { Measurement } \\
(\text { KPI })\end{array}$ & 2008 & 2009 \\
\cline { 2 - 4 } & ROI & $(94,608) \%$ & $(75,348) \%$ \\
\hline \multirow{3}{*}{ Financial } & ROE & $100 \%$ & $100 \%$ \\
\cline { 2 - 4 } & PM & $(18,727) \%$ & $(14,582) \%$ \\
\cline { 2 - 4 } & SG & $9,074 \%$ & $5,033 \%$ \\
\cline { 2 - 4 } & Complaint & $0,855 \%$ & $0,432 \%$ \\
\hline \multirow{2}{*}{ Customer } & New Customer & $2,440 \%$ & $2,112 \%$ \\
\cline { 2 - 4 } & \multicolumn{2}{|c|}{ Years } \\
\hline
\end{tabular}




\begin{tabular}{|c|c|c|c|}
\hline Internal Business & Transaction & $1,857 \%$ & $4,485 \%$ \\
\cline { 2 - 4 } Process & PSDM & $1,095 \%$ & $1,127 \%$ \\
\hline \multirow{2}{*}{$\begin{array}{c}\text { Learning and } \\
\text { Growth }\end{array}$} & Absent & $0,813 \%$ & $1,200 \%$ \\
\cline { 2 - 4 } & ETO & $7,143 \%$ & $7,643 \%$ \\
\cline { 2 - 4 } & ET & $50,376 \%$ & $40,762 \%$ \\
\hline
\end{tabular}

\section{Performance Measurement Balanced Scorecard With Weighting Factor}

\section{Financial Perspective}

From the measurement of critical success factors, only for the financial perspective to recap and determined each score (table 4.10), such as following table:

Table 4.15 Scoring Benchmark Financial Perspective

\begin{tabular}{|c|c|c|c|c|}
\hline \multirow[b]{2}{*}{$\begin{array}{c}\text { Standar } \\
\text { d } \\
\text { measure } \\
\text { ment } \\
(\mathrm{KPI})\end{array}$} & \multicolumn{2}{|l|}{2008} & \multicolumn{2}{|l|}{2009} \\
\hline & $\begin{array}{c}\text { Measurement } \\
\text { Result }\end{array}$ & $\begin{array}{l}\mathrm{S} \\
\mathrm{c} \\
\mathbf{o} \\
\mathbf{r} \\
\mathrm{e}\end{array}$ & $\begin{array}{c}\text { Measurement } \\
\text { Result }\end{array}$ & $\begin{array}{l}\mathrm{S} \\
\mathbf{c} \\
\mathbf{o} \\
\mathbf{r} \\
\mathrm{e}\end{array}$ \\
\hline ROI & $(94,608) \%$ & 1 & $(75,348) \%$ & 1 \\
\hline ROE & $100 \%$ & 3 & $100 \%$ & 3 \\
\hline $\mathrm{PM}$ & $(18,727) \%$ & 1 & $(14,582) \%$ & 1 \\
\hline $\mathrm{SG}$ & $9,074 \%$ & 2 & $5,033 \%$ & 1 \\
\hline
\end{tabular}

After scoring each measure was done weighting each measure is multiplied by the score. The results are shown in table 4.20, the following:

Table 4.16 Weighted Score Calculation Financial Perspective

\begin{tabular}{|c|c|c|c|c|c|c|}
\hline \multirow{2}{*}{$\begin{array}{c}\text { Standard } \\
\text { Measurement } \\
(\text { KPI) }\end{array}$} & \multicolumn{3}{|c|}{$\mathbf{2 0 0 8}$} & \multicolumn{3}{|c|}{$\mathbf{2 0 0 9}$} \\
\cline { 2 - 7 } & Score & Weight & $\begin{array}{c}\text { Weighted } \\
\text { Score }\end{array}$ & Score & Weight & $\begin{array}{c}\text { Weighted } \\
\text { Score }\end{array}$ \\
\hline ROI & 1 & 0,373 & 0,373 & 1 & 0,373 & 0,373 \\
\hline ROE & 3 & 0,228 & 0,684 & 3 & 0,228 & 0,684 \\
\hline PM & 1 & 0,234 & 0,234 & 1 & 0,234 & 0,234 \\
\hline SG & 2 & 0,166 & 0,332 & 1 & 0,166 & 0,166 \\
\hline & \multicolumn{3}{|c|}{ Total } & $\mathbf{1 , 6 2 3}$ & \multicolumn{3}{|c|}{ Total } & $\mathbf{1 , 4 5 7}$ \\
\hline
\end{tabular}

So from the above that the weighted score of the financial perspective for 2008 amounted to 1.623 and in 2009 amounted to 1.457 .

\section{Customer Perspective}

From the measurement of critical success factors, only for the customer perspective and determined to the recap scorenya (table 4.11), such as the following table:

Table 4.17 Scoring Benchmark Customer Perspective

\begin{tabular}{|c|c|c|c|c|}
\hline \multirow{2}{*}{$\begin{array}{c}\text { Standard } \\
\text { measurement } \\
\text { (KPI) }\end{array}$} & \multicolumn{2}{|c|}{$\mathbf{2 0 0 8}$} & \multicolumn{2}{c|}{$\mathbf{2 0 0 9}$} \\
\cline { 2 - 5 } & $\begin{array}{c}\text { Measurement } \\
\text { Result }\end{array}$ & Score & $\begin{array}{c}\text { Measurement } \\
\text { Result }\end{array}$ & Score \\
\hline CC & $0,855 \%$ & 3 & $0,432 \%$ & 2 \\
\hline NC & $2,440 \%$ & 2 & $2,112 \%$ & 2 \\
\hline
\end{tabular}

After scoring each measure was done weighting each measure is multiplied by the score. The results are shown in table 4.22 , the following: 
Table 4.18 Weighted Score Calculation Customer Perspective

\begin{tabular}{|c|c|c|c|c|c|c|}
\hline \multirow{2}{*}{$\begin{array}{c}\text { Standard } \\
\begin{array}{c}\text { Measurement } \\
\text { (KPI) }\end{array}\end{array}$} & $\begin{array}{c}\text { Sc } \\
\text { or } \\
\text { e }\end{array}$ & Weight & $\begin{array}{c}\text { Weighted } \\
\text { Score }\end{array}$ & $\begin{array}{c}\text { Sc } \\
\text { ore }\end{array}$ & $\begin{array}{c}\text { Weig } \\
\text { ht }\end{array}$ & $\begin{array}{c}\text { Weighte } \\
\text { d } \\
\text { Score }\end{array}$ \\
\hline CC & 3 & 0,500 & 1,500 & 2 & 0,500 & 1,000 \\
\hline NC & 2 & 0,500 & 1,000 & 2 & 0,500 & 1,000 \\
\hline & \multicolumn{2}{|c|}{ Total } & $\mathbf{2 , 5 0 0}$ & \multicolumn{2}{c|}{ Total } & $\mathbf{2 , 0 0 0}$ \\
\hline
\end{tabular}

So from the above that the weighted score of the customer perspective to the year 2008 amounted to 2.500 and in 2009 amounted to 2.000.

Internal Business Process Perspective

From the measurement of critical success factors, only for internal business process perspective and determined to the recap each score (table 4.12), such as the following table:

Table 4.19 Scoring Benchmark Internal Business Process Perspective

\begin{tabular}{|c|c|c|c|c|}
\hline $\begin{array}{c}\text { Standard } \\
\text { Measurement } \\
\text { (KPI) }\end{array}$ & \multicolumn{2}{|c|}{$\mathbf{2 0 0 8}$} & \multicolumn{2}{c|}{2009} \\
\cline { 2 - 5 } & $\begin{array}{c}\text { Measurement } \\
\text { Result }\end{array}$ & Score & $\begin{array}{c}\text { Measurement } \\
\text { Result }\end{array}$ & Score \\
\hline NT & $1,857 \%$ & 1 & $4,485 \%$ & 2 \\
\hline HRP & $1,095 \%$ & 2 & $1,127 \%$ & 2 \\
\hline
\end{tabular}

After scoring each measure was done weighting each measure is multiplied by the score. The results are shown in table 4.24 , the following:

Table 4.20 Calculation of Weighted Score Internal Business Process Perspective

\begin{tabular}{|c|c|c|c|c|c|c|}
\hline \multirow{2}{*}{$\begin{array}{c}\text { Standard } \\
\text { Measurement } \\
\text { (KPI) }\end{array}$} & \multicolumn{3}{|c|}{2008} & \multicolumn{3}{|c|}{2009} \\
\hline & Score & Weight & $\begin{array}{c}\text { Weighted } \\
\text { Score }\end{array}$ & Score & Weight & $\begin{array}{c}\text { Weighted } \\
\text { Score }\end{array}$ \\
\hline NT & 1 & 0,270 & 0,270 & 2 & 0,270 & 0,540 \\
\hline \multirow[t]{2}{*}{ HRP } & 2 & 0,730 & 1,460 & 2 & 0,730 & 1,460 \\
\hline & \multicolumn{2}{|c|}{ Total } & 1,730 & \multicolumn{2}{|c|}{ Total } & 2,000 \\
\hline
\end{tabular}

So from the above that the weighted score for internal business process perspective to the year 2008 amounted to 1.730 and in 2009 amounted to 2.000 .

\section{Learning and Growth Process Perspective}

From the measurement of critical success factors, only for the financial perspective and determined to the recap each score (table 4.13), such as the following table:

Table 4.21 Scoring Benchmark Process Perspective Learning and Growth

\begin{tabular}{c|c|c} 
Standard & 2008 & 2009 \\
\hline
\end{tabular}




\begin{tabular}{|c|c|c|c|c|}
\hline $\begin{array}{c}\text { Measurement } \\
\text { (KPI) }\end{array}$ & $\begin{array}{c}\text { Measurement } \\
\text { Result }\end{array}$ & Score & $\begin{array}{c}\text { Measurement } \\
\text { Result }\end{array}$ & Score \\
\hline ABS & $0,813 \%$ & 2 & $1,200 \%$ & 1 \\
\hline ETO & $7,143 \%$ & 2 & $7,643 \%$ & 2 \\
\hline ET & $50,376 \%$ & 3 & $40,762 \%$ & 2 \\
\hline
\end{tabular}

After scoring each measure was done weighting each measure is multiplied by the score. The results are shown in table 4.26 , the following:

Table 4.22 Weighted Score Calculation

Learning and Growth Process

\begin{tabular}{|c|c|c|c|c|c|c|}
\hline \multirow{2}{*}{$\begin{array}{c}\text { Standard } \\
\begin{array}{c}\text { Measurement } \\
\text { (KPI) }\end{array}\end{array}$} & Score & Weight & $\begin{array}{c}\text { Weighted } \\
\text { Score }\end{array}$ & Score & Weight & $\begin{array}{c}\text { Weighted } \\
\text { Score }\end{array}$ \\
\cline { 2 - 7 } & 2 & 0,177 & 0,354 & 1 & 0,177 & 0,177 \\
\hline ABS & 2 & 0,229 & 0,458 & 2 & 0,229 & 0,458 \\
\hline ETO & 3 & 0,594 & 1,782 & 2 & 0,594 & 1,188 \\
\hline ET & \multicolumn{3}{|c|}{ Total } & $\mathbf{2 , 5 9 4}$ & \multicolumn{3}{c|}{ Total } & $\mathbf{1 , 8 2 3}$ \\
\hline
\end{tabular}

So from the above that the weighted score process perspective and learning and growth for 2008 amounted to 2.594 and in 2009 amounted to 1.823 .

The following table is a recapitulation of the performance measurement results from 2008 and 2009, for each perspective with a weighting scored:

Table 4.23 Summary of Performance Measurement

Each Perspective by its Weighting Score

\begin{tabular}{|c|c|c|}
\hline Balanced Scorecard & $\mathbf{2 0 0 8}$ & $\mathbf{2 0 0 9}$ \\
\hline Financial Perspective & 1,623 & 1,457 \\
\hline Customer Perspective & 2,500 & 2,000 \\
\hline Internal Business Process Perspective & 1,730 & 2,000 \\
\hline Learning and Growth Process Perspective & 2,594 & 1,823 \\
\hline
\end{tabular}

To measure the performance with the Balanced Scorecard to include weighting factors perspective, the results shown in Table 4:28 below:

Table 4.24 Performance Measurement Balanced Scorecard In Comprehensive

\begin{tabular}{|c|c|c|c|c|c|c|}
\hline \multirow[b]{2}{*}{ BSC } & \multicolumn{3}{|c|}{2008} & \multicolumn{3}{|c|}{2009} \\
\hline & Score & Weight & $\begin{array}{l}\text { Weighted } \\
\text { Score }\end{array}$ & Score & Weight & $\begin{array}{l}\text { Weighted } \\
\text { Score }\end{array}$ \\
\hline Fin. & 1,623 & 0,265 & 0,431 & 1,457 & 0,265 & 0,386 \\
\hline Cust. & 2,500 & 0,278 & 0,695 & 2,000 & 0,278 & 0,556 \\
\hline Business & 1,730 & 0,249 & 0,430 & 2,000 & 0,249 & 0,498 \\
\hline Learning & 2,594 & 0,208 & 0,540 & 1,823 & 0,208 & 0,380 \\
\hline & \multicolumn{2}{|c|}{ Total } & 2,096 & \multicolumn{2}{|c|}{ Total } & 1,820 \\
\hline
\end{tabular}

The result of company's performance score in 2008 amounted to 2.096 and in 2009 amounted to 1.820 .

Criteria for assessment of the total results of the assessment taken by the score. The range between the largest and smallest score divided by the number of classes, in

this case is 3 then obtained value is 0.67 so the limitation assessment: 
$1,00 \leq$ total measurement results $\leq 1,67$

$1,68 \leq$ total measurement results $\leq 2,35$

$2,36 \leq$ total measurement results $\leq 3,00$

So the total score of PT performance measurement results. State Electricity Company, South Surabaya in 2008 was 2.096 (table 4.28) can be classified as adequate and firm performance in 2009 was 1.820 (table 4.28) can be classified fairly firm performance. Analysis of Performance Measurement Balanced Scorecard Result

Measurement Balanced Scorecard to the four perspectives, namely financial perspectives (finance perspective), the customer perspective (customer perspective), internal business process perspective (internal business process perspective), as well as learning and growth perspective (learning and growth perspective Process) in a comprehensive manner. In accordance with the table 4:18, for the financial perspective on the benchmark ROI (Return on Investment) increased in 2008 to 2009, from (94.608)\% to $(75.348) \%$. Then to measure the ROE (Return on Equity) in 2008 amounted to $100 \%$ has not changed in the year 2009 remains at $100 \%$. Benchmarks PM (profit margin) in 2008 amounted to (18.727)\% increase in 2009 amounted to (14.582)\%. And to measure SG (Sales growth) experienced a significant decline in the year 2008 to year 2009 from $9.074 \%$ to $5.033 \%$.

At the customer's perspective, benchmark percentage of customer complaints (Number of Customer Complaints) in 2008 amounted to $0.855 \%$, decreased by up to $0.432 \%$ in 2009 . Then to measure the percentage of the number of new customers (Number of New Customer) in 2008 amounted to $2.440 \%$ and decreased to $2.112 \%$ in 2009.

On the internal business process perspective, measures the percentage of the number of transactions (Number of Transaction) in 2008 amounted to $1.857 \%$, an increase of up to $4.485 \%$ in 2009. Then to measure the productivity of human resources in 2008 amounted to $1.095 \%$ and increased up to $1.127 \%$ in 2009.

Perspectives on the process of learning and growth benchmarks absenteeism increased in 2008 from $0.813 \%$ to $1.200 \%$ in 2009 . Then to measure ETO (Employee Turn Over) in 2008 amounted to $7.143 \%$ increase in 2009 amounted to $7.643 \%$. Benchmarks ET (Employee Training) in 2008 amounted to $50.376 \%$, a decrease of $40.762 \%$.

Criteria for assessment of the total results of the assessment taken by the score. The range between the largest and smallest score divided by the number of classes, in this case is 3 then obtained value is 0.67 so the limitation assessment:

$1,00 \leq$ total measurement results $\leq 1,67$

$1,68 \leq$ total measurement results $\leq 2,35$

$2,36 \leq$ total measurement results $\leq 3,00$

Less tompany Performance

Fuate Company Performance

God_Company Performance

So the total score of PT performance measurement results. State Electricity Company, South Surabaya in 2008 was 2.096 (table 4.28) can be classified as adequate and firm performance in 2009 was 1.820 (table 4.28) can be classified fairly firm performance.

\section{Proposed Improvement Company Performance}

After doing the analysis and comparison of performance measurement in 2008-2009 the company's performance must be followed up by giving the proposed strategy for improving the performance of each perspective.

The proposed increase is given to benchmark performance on the whole perspective of Balanced Scorecard is not appropriate attainment targets so that company need to perform corrective measures.

Proposed Improved Financial Performance in Perspective 
Performance PT. State Electricity Company reviewed the Financial Perspective has decreased from 2008 to 2009, so there are some benchmarks that are still yet to reach the target, therefore, the company still needs a better strategy to maintain and improve its performance, among others:

1. Improving the ability of companies in financial sufficiency, achieving annual performance in accordance with the CBP has been determined.

2. Made efforts to reduce debt by increasing sales to increase corporate cash.

3. Reducing expenditures for operating expenses for acquired more leverage. Proposed Performance Improvement in Customer Perspective

Judging from the overall company performance in 2008-2009 in the Customer Perspective is good. Although, the performance of Customer Perspective in the year 2009 decreased when viewed from the percentage value compared with 2008, although not too much, but there are some benchmarks that are still yet to reach the target.

Value of Customer Complaints benchmarks (CC) has decreased the value of which has reached the target percentage, the number of customer complaints is an important benchmark because with the number of complaints from customers, the consumers will feel less satisfied with services provided by the company, company image in the eyes of consumers the worse the impact on the decline in customer loyalty. Customer complaints is due to incompatibility with consumer demand, this case continuously will hurt the company even though consumers can tolerate.

In order to achieve the target company's strategy can be carried out include:

1. Increasing market share with promotions.

2. Maintaining a good service to customers during this instance with the ease of booking procedures.

3. Conduct surveys / collecting information about the state of the market (market segmentation).

\section{Proposed Improved Performance in Internal Business Perspective}

Viewed overall company performance in the Internal Business Process Perspective, the company's performance in the year 2008-2009 is the best proportion.

The increase from 2008 to 2009 can be seen in the percentage and value benchmarks Number of Transaction already reached the target company but on the percentage of the productivity of human resources benchmarks are not met the target.

In order to achieve the target company's strategy can be carried out include:

1. Conducting training and continuous training for employees.

2. The use of smaller input to produce a larger output means increased productivity is achieved if the company put all its ability to work more effectively in generating output and the costs incurred cultivated as low as possible.

Proposed Improved Performance In Learning and Growth Perspective

Judging from the overall company performance in the Learning and Growth Perspective in 2008-2009 enough, Learning and Growth Perspective performance in the year 2009 decreased when viewed from the percentage value compared with 2008 , although not too much. But there are some benchmarks that are still yet to reach the target.

Absenteeism benchmarks (number of absences) decreased the percentage value. The decline was the decreasing number of employees who do not come to work. Companies still need a better strategy to maintain and enhance its performance include:

1. Give an award such as salary increases, allowances, etc. to employees whose performance is good or employees who have long worked in the company (at least 5 years).

2. Provide additional bonuses or fees to an employee whose performance may exceed the target. 
Reinforce the rules concerning attendance for employees to improve the discipline and sense of responsibility the employee will work.

\section{Acknowledgement}

Several conclusions can be drawn from the results of this study are as follows:

1. Performance measurement PT. Perusahaan Listrik Negara, South Surabaya, in 2008 has 2.096 score can therefore be classified as adequate criteria, and in 2009 increased to 1,820 which is classified adequate criteria. Comparison of each perspective is as follows:

a. Financial Perspective

Performance of the Financial Perspective in 2008 have a weighted score of 1,623 which is classified less criteria, and in 2009 increased to 1,457 are classified as less criteria.

b. Customer perspective

Customer Performance Perspective in 2008 have a weighted score of 2,500 is good criteria and the criteria listed for an increase of 2,000 in 2009 to be classified as less criterion.

C. Internal Business Process Perspective

Internal Business Process Perspective Performance in 2008 has a weighted score of 1,730 is classified as adequate criteria and have increased in 2009 to 2,000 as adequate criteria classified.

d. Learning and Growth Process Perspective

Performance Process Perspective Learning and Growth in 2008 has a weighted score of 2,594 is good criteria and the criteria listed in 2009 decreased to 1,823 are classified as less criteria.

2. AHP results are respectively perspective showing the need for improvement in the process of learning and growth perspectives, among others:

a. Give an award such as salary increases, allowances, etc. to employees whose performance is good or employees who have long worked in the company (at least 5 years).

b. Provide an additional bonus or fees to an employee whose performance may exceed the target.

c. Reinforce the rules concerning attendance for employees to improve the discipline and sense of responsibility the employee will work.

\section{References}

Gaspersz, V. (2003). Sistem Manajemen Kinerja Terintegrasi Balanced Scorecard Dengan Six Sigma Untuk Organisasi Bisnis Dan Pemerintah. Jakarta: Penerbit PT Gramedia Pustaka Utama.

Husnan, Suad, And Heidjahrahman, R. (1995). Manajemen Personalia, Edisi keem(Penerbit BPFE), Yogyakarta.

Kaplan, R. . D. N. (1996). Translating Strategy Into Action-The Balanced Scorecard. Harvard Business School Press.

Mulyadi. (2001). Balanced Scorecard: Alat Manajemen Kontemporer untuk Pelipatganda Kinerja Keuangan Perusahaan,. Jakarta: Penerbit Salemba Empat.

Olve, Roy, and W. (1999). Performance Drivers: A Practical Guide To Using The Balanced 
Scorecard. Chicester, John Wiley and Son.

Render, Barry, and Jay, H. (2001). Prinsip-Prinsip Manajemen Operasi. Jakarta: Penerbit Salemba Empat.

Richard L. Lynch and Kelvin F. Cross. (1993). Performance Measurement System: Handbook Of Cost Management,. Peny. Bary Brinker, New York: Warren Gorham lamont, E3.

Rico, D. F. (n.d.). A Framework for Measuring the ROI of Enterprise Architecture. Retrieved from www.igi-global.com/files/prefaces/joeuc preface 18(2).pdf

Saaty, T. L. (1993). Pengambilan Keputusan Bagi Para Pemimpin. Jakarta: PT Pustaka Binaman Pressindo.

Safirin, M. (2002). Metodologi Penelitian. Surabaya: Penerbit Unesa Press.

Sunarjo, Indryati, and Hari, L. (1995). Manajemen SumberDaya Manusia. Bandung: Penerbit ITB. Supriyono, R. A. (1998). Manajemen Strategi Dan Kebijaksanaan Bisnis. Jakarta: Penerbit BPFE. Yuwono, Sony, Sukarno, Edy, and Ichsan, M. (2002). Balanced Scorecard: Menuju Organisasi Yang Berfokus Pada Strategi. Jakarta: Penerbit Gramedia Pustaka Utama. 